\title{
Administrative Mechanism of Joint Participation and Cooperation in the Early Stages of the COVID-19 Outbreak in Wuhan
}

This article was published in the following Dove Press journal: Risk Management and Healthcare Policy

Jingjing Yan'

Dahai Zhao',2

'School of International and Public Affairs, Shanghai Jiao Tong University, Shanghai, People's Republic of China; ${ }^{2}$ Shanghai Jiao Tong University-Yale University Joint Center for Health Policy, Shanghai, People's Republic of China

Correspondence: Dahai Zhao

School of International and Public Affairs, Shanghai Jiao Tong University, No. 1954

Huashan Road, Shanghai 200030, People's

Republic of China

Tel +86 I39-1896-8766

Email dahaizhao@sjtu.edu.cn
Introduction: From December 2019 to January 2020, a novel coronavirus disease (officially COVID-19) was reported in Wuhan and continued to spread all China. This study describes the administrative mechanism of joint participation and cooperation during the early stages of the COVID-19 outbreak in Wuhan and the rest of the country by health practitioners and administrative authorities.

Methods: This study adopted a qualitative design. An analytical framework based on the theory of policy participation that included stimulus, setting, and position of policy participation was constructed. Qualitative data of policy participation by health practitioners and administrative authorities consisted of publicly available data.

Results: Early during the outbreak, from December 2019 to January 2020, three main stages occurred according to the containment situation. The first stage was characterized by limited knowledge of the transmission dynamics of the virus and a consequently weak response. In the second stage, the disease spreads rapidly because of travel during a national festival. In the third stage, particularly when top Chinese leaders delivered instructions to intensify containment efforts, diverse departments initiated joint prevention and control measures to combat COVID-19.

Conclusion: The administrative mechanism of joint participation and cooperation was instrumental in avoiding a substantial increase in both cases and fatalities in the initial stage of the outbreak. This joint participation provides valuable experience and initiatives for major public health emergency preparedness, and the new empirical evidence further highlights the importance of policy participation theory in epidemic prevention in other countries.

Keywords: joint administration, coronavirus disease 2019, public health emergency, policy participation

\section{Introduction}

The coronavirus disease 2019 (COVID-19) health emergency has posed extensive threats to global health. ${ }^{1}$ Since December 2019, after several people with similar symptoms were admitted to hospitals in Wuhan, the disease has aroused great concern in the global health sector because of exposure history to the same locations $^{2}$ and the transmission dynamics in the general public. ${ }^{3}$ By February 4 , 2020, more than 20,623 confirmed cases (20,569 in China) and over 400 deaths had been reported. ${ }^{4}$ Since then, the mounting number of cases and deaths have resulted in a severe public health crisis and governance challenges on a global scale. ${ }^{5}$ 
During the early stages of the outbreak, when the transmission route of COVID-19 was still unclear, the administrative mechanism of joint participation and cooperation was adopted. ${ }^{6}$ Administrative measures and public health procedures focused on controlling further spread and treating infected patients. Indeed, a joint administrative approach to public affairs management has revealed favorable results and outcomes when applied to the control of environmental pollution and health care improvement. ${ }^{7,8}$ However, the effectiveness of a joint administrative mechanism during a health emergency and risk management remains unclear.

The administrative mechanism of joint participation and cooperation in COVID-19 preparedness resulted in improvements in sustainable health care cooperation and health outcomes early during the outbreak. Governments should now make adjustments in their procedures on the basis of past shortcomings and deficiencies. This study elucidates joint administration and cooperation from the perspective of policy participation according to the experience of combating COVID-19 during the early stages of the outbreak. This study found that policy participation can expand beyond public participation in political activities to multisector participation in public health crisis management. Because of the ongoing losses and policy adaptations, this path could serve as a reference for international health practice in responding to COVID-19 containment and global health management.

\section{Methods}

In times of social change, government operations are more likely to increase. ${ }^{9}$ During these changes and opportunities, structural conditions of governmental processes are created with scope for participation. ${ }^{10}$ Participation leads to power, but power requires participation as well. ${ }^{11}$ This is alluded to in Alford and Friedland's definition of political participation. Furthermore, Milbrath expanded the concept by specifying the dimensions of participation and their correlation with stimuli, factors and settings, and positions. ${ }^{12}$

This study involved an empirical analysis of policy participation between health practitioners and government administrators. We investigated the role of policy participation in public health and crisis management through joint administration and cooperation. According to the theoretical framework of policy participation, we focused on the stimuli, settings, and positions of health practitioners and administrative officials in terms of their preparedness.
Qualitative data of policies were collected from both health practitioners and administrative departments.

This process proceeded in three steps. The first involved identifying the practitioners who participated in crisis management in terms of decision making and health behaviors. Second, qualitative data were collected through publicly available data and from official websites regarding the key responses and guidelines provided by the confirmed practitioners. Data were collected between December 30, 2019, when Wuhan first publicly reported cases, and January 24, 2020, the beginning of the study. Third, we reviewed the data to determine whether it was reliable and complete, and we discussed it according to the analytical framework.

\section{Results}

Table 1 reveals the timeline of events in the initial stages of the outbreak. After several patients were diagnosed with pneumonia in Wuhan and a connection was made with the unknown viral infection from the Huanan Seafood Wholesale Market, ${ }^{2}$ health and administrative authorities in Wuhan and upper-level authorities implemented a series of countermeasures to prevent the wider spread of the disease.

\section{Wuhan Health Department}

\section{First Reports of Unexplained Viral Pneumonia}

On December 30, 2019, the Wuhan Health Department issued a notification entitled "Urgent Notice on the Treatment of Pneumonia with Unknown Causes." They announced that several cases of pneumonia had been identified in people with a travel history to the Seafood Wholesale Market. ${ }^{13}$ The early notification only reported the number of infections and the situation of critically ill patients. Initial countermeasures included only isolation and symptomatic treatment because limited information was available on the origins of the disease. As the crisis evolved, more stringent public health procedures, such as medical observation of close contacts of those confirmed with the disease and epidemiological investigation of the Seafood Wholesale Market, were implemented, particularly when rumors regarding the disease spread extensively.

\section{No New Cases Reported in the Following Six Notifications}

After confirmation through clinical and laboratory tests, the Wuhan Health Department believed that the identified cases of unexplained viral pneumonia had occurred between December 8, 2019, and January 2, 2020; no new 
Table I Early Preparedness and Response Taken by Administrative Authorities and Health Practitioners to Combat COVID-I9 Outbreak

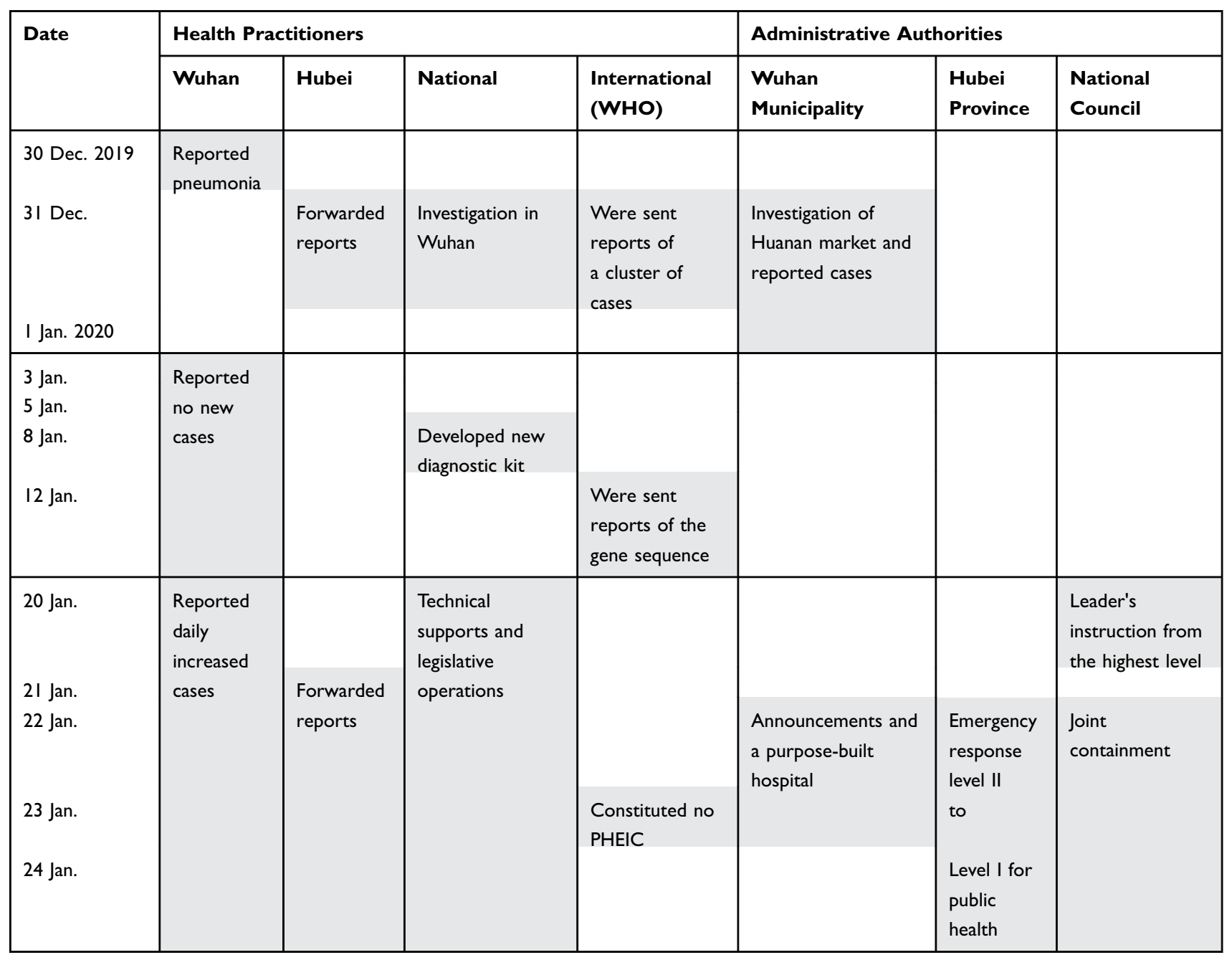

cases were found after January 3. Those confirmed as having the disease included staff of the Seafood Wholesale Market. This was communicated through public health notifications on January $3,5,11,12$, and 13 . On January 11, the Wuhan Health Department announced that some patients had been discharged from hospital and that their close contacts were free from medical observation. ${ }^{14}$

\section{Sudden Outbreak Triggering Public Health Emergencies}

The gravity of the situation drastically escalated on January 13, after Thailand, Japan, and neighboring countries reported several pneumonia cases. ${ }^{15,16}$ Although another notification issued by the Wuhan Health Department on January 16 still indicated no increase in the number of cases, ${ }^{17}$ a dramatic change occurred on January 17 , when pneumonia cases suddenly began to rise steeply every day. ${ }^{18}$

\section{Wuhan Municipality}

\section{An Interview with the Mayor}

The mayor of Wuhan explained the situation on national television on January 22, when the outbreak had already generated great concern nationwide. The following is a translated extract from the interview with the mayor.

There were insufficient early warnings. Festival celebrations proceeded because previous judgments indicated that pneumonia was limited to human-to-human transmission. By the time of the festival, more than 5 million migrants in Wuhan planned to travel elsewhere, and many people began to return to their hometown of Wuhan. ${ }^{19}$

To some extent, the Wuhan municipality expected to reduce the number of people at the festival to control the virus spread and reduce the pressure of local containment. $^{20}$ Compared with the extremely strict measures implemented in the rest of the country after the 
spread, the key epidemic area generated coping strategies on the basis of critical evidence regarding whether medical workers were infected and whether human-to-human transmission was possible. ${ }^{21,22}$ However, uncertainty led to obstacles in early overall decision making.

\section{Announcements and a Purpose-Built Hospital}

On January 20, Wuhan municipality established headquarters that served as the leading department for COVID-19 prevention and control. Eight announcements within 2 days were issued following the establishment of the headquarters. Announcement no. 1 was issued on January 23, which dictated the suspension of buses, subways, ferries, and other long-distance passenger transport in the city. ${ }^{23}$ This announcement was the initial stage of officially placing Wuhan under lockdown. Announcement no. 2 declared the suspension of all transportation to and from Wuhan. ${ }^{19}$ Under these circumstances, appropriate arrangements were made for protecting people's living conditions after the closure of the city, such as the provision of food and medical supplies. The third ${ }^{24}$ and fourth ${ }^{25}$ announcements concerned donations of personal protective and medical equipment and other daily necessities. No. 5 suspended online taxi-hailing services because residents were required to stay at home. ${ }^{26}$ No. 6 was issued on January 24 and announced the closure of traffic across the Yangtze River. ${ }^{27}$ This further strengthened the closure of the city to unprecedented levels. No. 7 focused on solutions to medical treatment problems, such as long waiting times at outpatient clinics and delayed hospital admission. ${ }^{28}$ More fever clinics and a tiered system for medical treatments were established in Wuhan. No. 8 declared that the city urgently required 6000 taxis to provide auxiliary home services for free, such as food and medicine delivery, to further help residents adapt to daily life after the closure. ${ }^{29}$

Moreover, travel activities and large-scale recreational events as well as activities in parks, libraries, museums, and other cultural venues were suspended. ${ }^{30}$ The notification on wearing face masks in public places was issued on January 22, ${ }^{31}$ and a new purpose-built hospital (Lei Shen Shan) was announced on January $23 .{ }^{32}$ The measure of purpose-built was based on experience of large-scale treatment of an infectious disease during the severe acute respiratory syndrome (SARS) epidemic. This medical facilities received one-seventh of the whole country's patients with SARS within 2 months and effectively controlled the SARS epidemic in April 2003.

\section{Hubei Provincial Government Press Conferences on Combating COVID-19}

Because the outbreak was deteriorating, the Hubei Provincial Government held three press conferences regarding containment of the epidemic. During the first press conference on January 22, an outbreak in Wuhan was officially acknowledged, and an Emergency Response Level II for public health was declared for the entire province. ${ }^{33}$ This was upgraded to level I on January 24, the highest level for a public health emergency response. ${ }^{34}$ On January 23 , at the second press conference, the Hubei Provincial Bureau for Market Regulation announced an investigation to address wildlife crime and illegal trade. Officials also strengthened supervision of the trade in surgical masks and medical commodities by strictly prohibiting price fixing, bid rigging, and other collusive agreements in the market. The prices of agricultural products and online commodities were likewise monitored. ${ }^{35}$ On January 24, during the third press conference, officials announced that patients must be treated where they were first diagnosed, and referrals were permitted only when advanced medical treatment was necessary. ${ }^{36}$ This measure aimed to prevent nosocomial infections as panicked patients sought medical care.

\section{Open Letter to the People of Hubei}

On January 23, an open letter from Hubei's headquarters for the prevention and control of COVID-19 called on residents of the province to remain vigilant at all times regarding the pathogenicity and transmission of COVID19 among their people. The following is a translated extract from the letter.

It is the legal obligation of all units and individuals of our province to obey and cooperate in combating COVID-19. Individuals should pay attention to personal hygiene and proper indoor ventilation and disinfection. In public places, they must wear face masks. Patients with a fever must go to their nearest hospital. ${ }^{37}$

\section{National Health Commission} Technical Support and Legislative Decisions

After the outbreak of pneumonia was reported by Wuhan authorities, leaders and experts organized by the National Health Commission rushed to Wuhan to investigate the epidemiology and biology of this disease. ${ }^{38}$ On January 21, a high-level expert group, including members of the Chinese Academy of Engineering and leaders of central health departments, was assembled to compile 
a thorough report on the outbreak to inform the public. ${ }^{39}$ Human-to-human transmission and medical staff infection were then confirmed, which elevated the gravity of the outbreak. Since then, continually updated standards and guidelines for medical operations and laboratory biosafety have been introduced for the whole medical system of the country. ${ }^{40,41}$ On January 20, COVID-19 was officially listed as a National Notifiable Infectious Disease. ${ }^{42}$

\section{National Council and Departments Highest Instruction and Joint Participation}

On January 20, top leaders of the country delivered normreferenced instructions on the epidemic, requesting that people's health remain the top priority. ${ }^{43}$ In addition to addressing the developing crisis, the government actively engaged in cooperation with international health practitioners. ${ }^{44}$ On January 11, China shared the genetic sequence of COVID-19, which was detected in Wuhan. ${ }^{45}$ On January 22, the Joint Prevention and Control Mechanism of the State Council and the Leading Group of the Communist Party of China's Central Committee on the Prevention and Control of COVID-19, headed by the premier, established a decision-making interchange platform consisting of multiple ministries and governments at different levels for a comprehensive response to the epidemic. $^{46}$

The Ministry of Finance and the Medical Insurance Bureau offered flexible fiscal arrangements for treating patients with COVID-19. ${ }^{47}$ In the following 2 to 3 days, the Ministry of Finance allocated more subsidies for coronavirus financial support and loan relief to individuals and businesses affected by the outbreak. ${ }^{48}$ The National Administration of Traditional Chinese Medicine organized adjunct treatments involving traditional herbal therapy. ${ }^{49}$ The Ministry of Science and Technology launched a specialized fund aimed at encouraging the development of medicines and a vaccine for COVID- $19 .^{50}$ The Ministry of Transport and Civil Aviation Administration sought strict measures to halt the spread through transportation. ${ }^{51,52}$ The Ministry of Education enacted measures in the education system, such as conducting nationwide online teaching and delaying the start of the new semester. ${ }^{53}$ The Ministry of Human Resources and Social Security announced special protection for medical staff. $^{54}$ The Ministry of Civil Affairs called for monitoring the spread of the disease in older people, those with mental disabilities, and children. ${ }^{55}$

\section{International Health Departments} Whether to Declare a Public Health Emergency of International Concern

On December 31, 2019, the World Health Organization (WHO) China Office was informed of cases of unexplained pneumonia in Wuhan. ${ }^{9}$ On the basis of information available at that time, the WHO recommended against imposing travel or trade restrictions on China on January $5 .^{56}$ A week later, the WHO received the full gene sequence of the novel coronavirus pneumonia in Wuhan from the Chinese government. ${ }^{57}$ Because Chinese health practitioners had employed appropriate measures to combat COVID-19 and the number of cases outside China was limited, the WHO still maintained it was too early to declare a Public Health Emergency of International Concern on January $23 .{ }^{58}$

\section{Discussion}

As illustrated in Figure 1, the early outbreak had three main stages, which were affected by the stimuli, settings, and positions of administrative authorities and health practitioners from the perspective of policy participation.

\section{Stage One: Limited Awareness}

During the first stage, in terms of the position dimension of policy participation, only local health departments were positioned in public health preparedness. In particular, the health department of Wuhan city and the health administrative department of Hubei province implemented measures to mitigate the virus' spread. ${ }^{59}$ Other sectors outside the health administration had not yet become involved. In the behavioral setting, COVID-19 was treated as a common virus and had not yet reached the level of a major public health crisis. ${ }^{60}$ The predictions and estimates of the health risks of the outbreak were lower. ${ }^{61}$ However, cases of COVID-19 were reported in a timely manner, a reversal of the widely criticized opaque response during the SARS outbreak. On the stimulus side, no signs were observed as a response to the incipient outbreak. 27-04-2020-who-timelines of this stage are presented in Table 1. In sum, the first stage of the reaction to the crisis reflected a general situation of limited awareness and low management.

\section{Stage Two: Festival Flow}

During the second stage, national health authorities became involved in the investigation of the epidemic in terms of the position dimension of policy participation. 


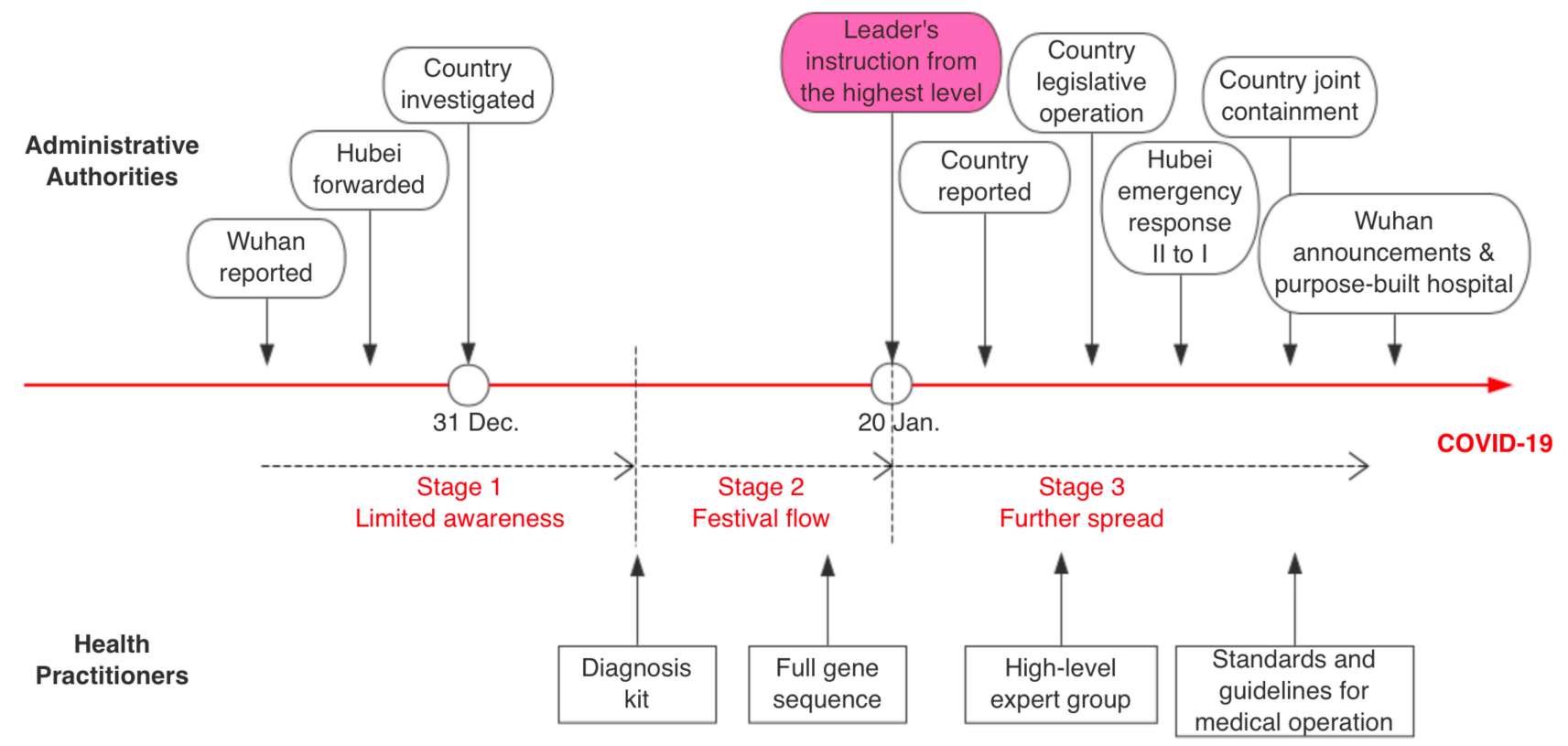

Figure I Early stages of COVID-19 outbreak in Wuhan.

Retrospective tracing conducted by the national health department of the first case in Wuhan revealed the spread to be through human-to-human transmission rather than a continuous spillover. ${ }^{62}$ In the behavioral setting, owing to robust health science and technological efforts, diagnostic techniques and genetic sequences were quickly developed and identified, respectively. ${ }^{57}$ However, on the stimulus side, the Lunar New Year Festival travel rush began during this stage, and more than 5 million people traveled out of Wuhan. ${ }^{19,63}$ Population flow and social interactions posed a critical threat to controlling the spread of the virus because people with no symptoms or mild symptoms could spread it. ${ }^{64}$ Faced with these concerns, the Chinese government extended the national holiday to fully cover the incubation period of suspected COVID-19 infection. ${ }^{65}$

\section{Stage Three: Further Spread}

During the SARS outbreak in 2003, China's health system was fragmented and poorly coordinated. However, during the COVID-19 outbreak, the Chinese health community revealed remarkable progress in both domestic health crisis response and global cooperation. ${ }^{66}$ After top leaders delivered their instructions for the management of the crisis, which served as a strong stimulus, joint prevention and control was implemented by diverse departments at the country level. In addition to medical and health care, various departments played their respective roles in epidemic prevention and control and in return-to-work economic resumption in terms of the position dimension of policy participation. In the behavioral setting, regulations governing the epidemic management of COVID-19 were adopted at the legislative level. In the key epidemic area, Wuhan constructed hospitals to expand admission capacity and Hubei raised its public health emergency level. At the national level, standardized operating procedures were formulated, and medical operations were executed according to constantly updated operating guidelines provided by a group of high-level experts from around the country. From this stage onward, both the administrative drive and medical response were promoted to the highest level of effectiveness ever achieved in the response to public health events by using policy participation.

\section{Conclusion}

From the early response, we found that the participation of different departments and their behavioral settings during the three stages greatly affected the development of the epidemic. A critical turning point in early preparedness occurred on January 20, when top leaders declared the prioritization of COVID-19 containment; this was the most obvious stimulus during the crisis. From that time, joint administration and participation has resulted in effective action on epidemic prevention and control throughout the country. In addition to domestic efforts, the most remarkable progress in policy participation in terms of 
controlling the early outbreak was achieved through transparent and mutual trusting cooperation with global health practitioners. Regrettably, wide awareness of disease prevention remains poor. Maintaining public health should be prioritized with an internalization manner of all individuals. This early joint preparedness and response to a major health emergency could serve as a reference for further efforts by health practitioners worldwide.

\section{Disclosure}

The authors report no conflicts of interest in this work.

\section{References}

1. Zhang N, Wang L, Deng X, et al. Recent advances in the detection of respiratory virus infection in humans. $J$ Med Virol. 2020;92 (4):408-417. doi:10.1002/jmv.25674

2. Kaplan EH. Containing 2019-nCoV (Wuhan) coronavirus. Health Care Manag Sci. 2020. doi:10.1007/s10729-020-09504-6

3. Huang C, Wang Y, Li X, et al. Clinical features of patients infected with 2019 novel coronavirus in Wuhan, China. Lancet. 2020;395 (10223):497-506. doi:10.1016/S0140-6736(20)30183-5

4. WHO. Data was collected at February 4, 2020. See more: rolling updates on coronavirus disease (COVID-19). Available from: https:// www.who.int/emergencies/diseases/novel-coronavirus-2019/eventsas-they-happen. Accessed February 4, 2020.

5. Phelan AL, Katz R, Gostin LO. The novel coronavirus originating in Wuhan, China: challenges for global health governance. JAMA. 2020;323(8):709-710. doi:10.1001/jama.2020.1097

6. Centers for Disease Control and Prevent. 2019 novel coronavirus (2019-nCoV) situation summary; 2020. Available from: https:// www.cdc.gov/coronavirus/2019-nCoV/summary.html?from=timeli ne\&isappinstalled $=0$. Accessed January 24, 2020.

7. Zhang NN, Ma F, Qin CB, et al. Spatiotemporal trends in PM2. 5 levels from 2013 to 2017 and regional demarcations for joint prevention and control of atmospheric pollution in China. Chemosphere. 2018;210:1176-1184. doi:10.1016/j.chemosphere.2018.07.142

8. WHO \& ILO. Joint WHO/ILO policy guidelines on improving health worker access to prevention, treatment and care services for HIV and TB; 2010. Available from: https://apps.who.int/iris/bitstream/handle/ 10665/44467/9789241500692_eng.pdf>. Accessed January 24, 2020.

9. Bishop BJ, Vicary DA, Browne AL, et al. Public policy, participation and the third position: the implication of engaging communities on their own terms. Am J Community Psychol. 2009;43(1-2):111-121. doi:10.1007/s10464-008-9214-8

10. Verba S, Nie NH Participation in America: political democracy and social equality; University of Chicago Press. 1987. Available from: https://books.googlebooks?hl=zh-CN/books?hl=zh-CN\&id $=9 \mathrm{~K} 5 \mathrm{fdvfmGREC} \& \mathrm{oi}=$ fnd $\& \mathrm{pg}=\mathrm{PR} 11 \& \mathrm{dq}=$ Participation + in + America:+Political+democracy+and+social+equality\&ots= EWWyGkEfYN\&sig=Jm6JXmjVfEpm8asHz-_4hU21 Gwg\&redir_ esc $=\mathrm{y} \# \mathrm{v}=$ onepage $\& \mathrm{q}=$ Participation $\% 20 \mathrm{in} \% 20$ America $\% 3 \mathrm{~A} \% 20$ Poli. Accessed January 24, 2020.

11. Alford RR, Friedland R. Political participation and public policy. Annu Rev Sociol. 1975;1(1):429-479. doi:10.1146/annurev. so.01.080175.002241

12. Milbrath LW, Goel ML Political participation: how and why do people get involved in politics? Chicago: Rand McNally \& Company. 1977. Available from: https://books.google.com.tw/books/ about/Political_Participation.html?id=SwsVAQAAIAAJ\&redir_esc $=$ y. Accessed January 24, 2020.
13. Wuhan Municipal Health Commission. Bulletin on the current pneumonia epidemic situation; 2020. Available from: http://wjw.wuhan. gov.cn/front/web/show27-04-2020-who-timeline/2020011209037. Accessed January 24, 2020. [in Chinese].

14. Wuhan Municipal Health Commission. Bulletin of Wuhan Municipal Health Commission on pneumonia caused by novel coronavirus infection; 2020. Available from: http://wjw.wuhan.gov.cn/front/web/ show27-04-2020-who-timeline/2020012009077. Accessed January 24, 2020. [in Chinese].

15. World Health Organiation. Novel coronavirus (2019-nCoV) situation report - 1; 2020. Available from: https://www.who.int/docs/defaultsource/coronaviruse/situation-reports/20200121-sitrep-1-2019-ncov. pdf?sfvrsn=20a99c10_4. Accessed January 24, 2020.

16. Wuhan Municipal Health Commission. Experts from Hong Kong, Macao and Taiwan visited our city; 2020. Available from: http:// wjw.wuhan.gov.cn/front/web/show27-04-2020-who-timeline/ 2020011509042. Accessed January 24, 2020. [in Chinese].

17. Wuhan Offical. Bulletin of Wuhan Municipal Health Commission on pneumonia caused by novel coronavirus infection; 2020. Available from: https://weibo.com/2759348142/IpOaZpk6G. Accessed January 24, 2020. [in Chinese].

18. Wuhan Offical. Bulletin of Wuhan Municipal Health Commission on pneumonia caused by novel coronavirus infection; 2020. Available from: https://weibo.com/2759348142/Iq7m2gmZ4. Accessed January 24, 2020. [in Chinese].

19. Wuhan Municipal Government. Municipal headquarters for the prevention and control of novel coronavirus pneumonia (Announcement no. 2); 2020. Available from: http://www.wh.gov.cn/hbgovinfo/ zwgk_8265/tzgg/202001/t20200124_304134.html. Accessed January 24, 2020. [in Chinese].

20. China Daily Hongkong. Mayor of Wuhan: stay away; 2020. Available from: https://www.chinadailyhk.com/article/119265. Accessed January 24, 2020. [in Chinese].

21. China Daily. Wuhan mayor says will resign if it helps control outbreak; 2020. Available from: http://www.china.org.cn/china/ 2020-01/28/content_75653894.htm. Accessed February 4, 2020. [in Chinese].

22. Li Q, Guan X, Wu P, et al. Early transmission dynamics in Wuhan, China, of novel coronavirus-infected pneumonia. $N$ Engl $J$ Med. 2020;382(13):1199-1207. doi:10.1056/NEJMoa2001316

23. Wuhan Municipal Government. Municipal headquarters for the prevention and control of novel coronavirus pneumonia (Announcement no. 1); 2020. Available from: http://www.wh.gov.cn/hbgovinfo/ zwgk_8265/tzgg/202001/t20200123_304065.html. Accessed January 24, 2020. [in Chinese].

24. Wuhan Municipal Government. Municipal headquarters for the prevention and control of novel coronavirus pneumonia (Announcement no. 3); 2020. Available from: http://www.wh.gov.cn/hbgovinfo/ zwgk_8265/tzgg/202001/t20200124_304135.html. Accessed January 24, 2020. [in Chinese].

25. Wuhan Municipal Government. Municipal headquarters for the prevention and control of novel coronavirus pneumonia (Announcement no. 4); 2020. Available from: http://www.wh.gov.cn/hbgovinfo/ zwgk_8265/tzgg/202001/t20200124_304136.html. Accessed January 24, 2020. [in Chinese].

26. Wuhan Municipal Government. Municipal headquarters for the prevention and control of novel coronavirus pneumonia (Announcement no. 5); 2020. Available from: http://www.wh.gov.cn/hbgovinfo/ zwgk_8265/tzgg/202001/t20200124_304137.html. Accessed January 24, 2020. [in Chinese].

27. Wuhan Municipal Government. Municipal headquarters for the prevention and control of novel coronavirus pneumonia (Announcement no. 6); 2020. Available from: http://www.wh.gov.cn/hbgovinfo/ zwgk_8265/tzgg/202001/t20200124_304143.html. Accessed January 24, 2020. [in Chinese]. 
28. Wuhan Municipal Government. Municipal headquarters for the prevention and control of novel coronavirus pneumonia (Announcement no. 7); 2020. Available from: http://www.wh.gov.cn/hbgovinfo/ zwgk_8265/tzgg/202001/t20200124_304146.html. Accessed January 24, 2020. [in Chinese].

29. Wuhan Municipal Government. Municipal headquarters for the prevention and control of novel coronavirus pneumonia (Announcement no. 8); 2020. Available from: http://www.wh.gov.cn/hbgovinfo/ zwgk_8265/tzgg/202001/t20200124_304147.html. Accessed January 24, 2020. [in Chinese].

30. Wuhan culture and tourism bureau. Several measures concerning the implementation of the Municipal Epidemic Prevention and Control Command (No. 1); 2020. Available from: http://wlj.wuhan.gov.cn/ zwgk 27/zwdt/gsgg/202003/t20200303 943664.shtml. Accessed January 24, 2020. [in Chinese].

31. Wuhan Municipal Government. Notice of implementing masks in public places; 2020. Available from: http://www.wh.gov.cn/hbgo vinfo/zwgk_8265/szfxxgkml/fggw/gfxwj/202001/t20200123_ 304117.html. Accessed January 24, 2020. [in Chinese].

32. Wuhan official. Wuhan will build another "Xiaotangshan Hospital" with 1300 new beds; 2020. Available from: https://weibo.com/ 2759348142/Ir8vf9QwK. Accessed February 4, 2020. [in Chinese].

33. Hubei Provincial Government. Hubei initiates level II emergency response to public health emergencies; 2020. Available from: http:// www.hubei.gov.cn/zwgk/hbyw/hbywqb/202001/t20200123_2014354. shtml. Accessed January 24, 2020. [in Chinese].

34. Hubei Provincial Government. Hubei initiates level $\square$ emergency response to public health emergencies; 2020. Available from: http:// www.hubei.gov.cn/zwgk/hbyw/hbywqb/202001/t20200125_2014863. shtml. Accessed February 4, 2020. [in Chinese].

35. Hubei Provincial Government. "Prevention and control on new coronavirus infected pneumonia epidemic" Press Conference $2^{\text {nd }} ; 2020$. Available from: http://www.hubei.gov.cn/hbfb/xwfbh/202001/ t20200123_2014594.shtml. Accessed January 24, 2020. [in Chinese].

36. Hubei Provincial Government. "Prevention and control on new coronavirus infected pneumonia epidemic" Press Conference $3^{\text {rd }} ; 2020$. Available from: http://www.hubei.gov.cn/hbfb/xwfbh/202001/ t20200124_2014794.shtml. Accessed January 24, 2020. [in Chinese].

37. Hubei Provincial Government. A letter to the people of the province; 2020. Available from: http://www.hubei.gov.cn/zhuanti/2020/ gzxxgzbd/zxtb/202001/t20200123_2014575.shtml. Accessed January 24, 2020. [in Chinese].

38. Wuhan official. Hubei "Wuhan found unknown cause pneumonia" Expert team has reached Wuhan; 2019. Available from: https:/weibo. com/2759348142/InihPzR1A. Accessed January 24, 2020. [in Chinese].

39. National Health Commission. High-level expert group of the National Health Commission responds to a reporter's question on the pneumonia epidemic of new coronavirus infection; 2020. Available from: http://www.nhc.gov.cn/xcs/fkdt/202001/ 8d735f0bb50b45af928d9944d16950c8.shtml. Accessed January 24, 2020. [in Chinese].

40. National Health Commission. Interpretation of pneumonia prevention and control plan for new coronavirus infection (Second Edition); 2020. Available from: http://www.nhc.gov.cn/xcs/fkdt/202001/ 301c8b00efa340ceb97d730a6c6ad36f.shtml. Accessed January 24, 2020. [in Chinese].

41. National Health Commission. Interpretation of new coronavirus laboratory biosafety guide (Second Edition); 2020. Available from: http://www.nhc.gov.cn/xcs/fkdt/202001/592dff68bdce45f19b b504e739e9c358.shtml. Accessed January 24, 2020. [in Chinese].

42. National Health Commission. Novel coronavirus-infected pneumonia included in legal infectious disease management; 2020. Available from: http://www.nhc.gov.cn/xcs/fkdt/202001/e4e 2 d5e 6 f01147e0a8df3f6701d49f33.shtml. Accessed January 24, 2020. [in Chinese].
43. National Health Commission. The party group of the National Health and Health Commission conveyed the spirit of implementing the important instructions of General Secretary Xi Jinping and the instructions of Premier Li Keqiang to study and deploy the pneumonia epidemic prevention and control of novel coronavirus infection; 2020. Available from: h t t p : / / w w w. n h c.gov. c n / x c s/fk d t/ $202001 /$ 135b650259f647869bf7558154e84d8d.shtml. Accessed January 24, 2020. [in Chinese].

44. Xinhuanet. Ministry of Foreign Affairs: china is willing to work with the international community to cope with the outbreak of new coronavirus pneumonia; 2020. Available from: http://www.gov.cn/xinwen/2020-01/ 21/content 5471342.htm. Accessed January 24, 2020. [in Chinese].

45. National Health Commission. China to share novel coronavirus gene sequence information with World Health Organization; 2020. Available from: http://www.nhc.gov.cn/xcs/fkdt/202001/ 422796acaea746549f93e617ccc348a1.shtml. Accessed January 24, 2020. [in Chinese].

46. National Health Commission. The National Health Commission and the relevant departments jointly prevent and control the pneumonia epidemic of new coronavirus infection; 2020. Available from: http://www.nhc.gov. $\mathrm{cn} / \mathrm{xcs} / \mathrm{fkdt} / 202001 / \mathrm{d} 9570 f 3 a 52614113 \mathrm{ae} 0093 \mathrm{df5} 1509684$.shtml. Accessed January 24, 2020. [in Chinese].

47. Ministry of Finance. Ministry of Finance and National Medical Insurance Bureau: ensure that patients with confirmed novel coronavirus pneumonia will not be affected by medical expenses; 2020 . Available from: http://www.gov.cn/xinwen/2020-01/22/content_ 5471714.htm. Accessed January 24, 2020. [in Chinese].

48. Ministry of Finance. In accordance with the deployment of the State Council, the Ministry of Finance has allocated 1 billion yuan for Hubei Province's novel coronavirus-infected pneumonia outbreak; 2020. Available from: http://www.gov.cn/xinwen/2020-01/23/con tent_5471917.htm. Accessed January 24, 2020. [in Chinese].

49. National Administration of Traditional Chinese Medicine. National Administration of Traditional Chinese Medicine establishes leading group for prevention and control of pneumonia epidemic in response to novel coronavirus infection; 2020. Available from: http://www.gov.cn/ xinwen/2020-01/23/content_5471872.htm. Accessed January 24, 2020. [in Chinese].

50. Ministry of Science and Technology. Ministry of Science and Technology and related departments jointly carry out emergency scientific research on novel coronavirus pneumonia; 2020. Available from: http://www.gov.cn/xinwen/2020-01/24/content_5471938.htm. Accessed January 24, 2020. [in Chinese].

51. Ministry of Transport. Ministry of Transport issues emergency notice: works closely with health and other departments to curb the spread of the epidemic; 2020. Available from: http://www.gov.cn/xinwen/2020-01/ 22/content_5471541.htm. Accessed January 24, 2020. [in Chinese].

52. Civil Aviation Administration. Civil Aviation Administration takes measures to intensify prevention and control of pneumonia outbreak of new coronavirus infection; 2020. Available from: http://www.gov.cn/xinwen/ 2020-01/23/content_5471843.htm. Accessed January 24, 2020. [in Chinese].

53. Ministry of Education. Ministry of Education deploys education system to prevent and control pneumonia of novel coronavirus infection; 2020. Available from: http://www.gov.cn/xinwen/2020-01/ 22/content_5471608.htm. Accessed January 24, 2020. [in Chinese].

54. Ministry of Human Resources and Social Security. Notice on the protection of medical staff and related staff members infected with novel coronavirus pneumonia due to work duties; 2020. Available from: http:/www.gov.cn/zhengce/zhengceku/2020-01/23/content_ 5471922.htm. Accessed January 24, 2020. [in Chinese].

55. Ministry of Civil Affairs. Ministry of Civil Affairs deploys civil service agencies to do a good job in prevention and control of novel coronavirus infection pneumonia; 2020. Available from: http://www.gov.cn/xinwen/2020-01/23/content_5471813.htm. Accessed January 24, 2020. [in Chinese]. 
56. WHO. WHO advice for international travel and trade in relation to the outbreak of pneumonia caused by a new coronavirus in China; 2020. Available from: https://www.who.int/news-room/articles-detail /who-advice-for-international-travel-and-trade-in-relation-to-theoutbreak-of-pneumonia-caused-by-a-new-coronavirus-in-china/. Accessed January 24, 2020. [in Chinese].

57. WHO. WHO Timeline - COVID-19. Updated on an ongoing basis; 2020. Available from: https://www.who.int/news-room/detail/27-04 2020-who-timeline-covid-19. Accessed January 24 and February 19, 2020. [in Chinese].

58. WHO. Statement on the meeting of the International Health Regulations (2005) Emergency Committee regarding the outbreak of novel coronavirus (2019-nCoV); 2020. Available from: https:// www.who.int/news-room/detail/23-01-2020-statement-on-themeeting-of-the-international-health-regulations-(2005)-emergencycommittee-regarding-the-outbreak-of-novel-coronavirus-(2019-ncov) . Accessed January 24, 2020.

59. Clark DR, Jonathan EM, Kenneth B. Clinical evidence does not support corticosteroid treatment for $2019-\mathrm{nCoV}$ lung injury. Lancet. 2020;2(395):473-475. doi:10.1016/S0140-6736(20)30317-2
60. Munster VJ, Koopmans M, van Doremalen N, et al. A novel coronavirus emerging in China - key questions for impact assessment. N Engl J Med. 2020;382(8):692-694. doi:10.1056/NEJMp2000929

61. Shi PP, Cao S, Feng PH. SEIR Transmission dynamics model of 2019 nCoV coronavirus with considering the weak infectious ability and changes in latency duration. medRxiv Preprint. 2020. doi:10.1101/ 2020.02.16.20023655

62. Heymann DL, Shindo N. COVID-19: what is next for public health? Lancet. 2020;395(10224):542-545. doi:10.1016/S0140-6736(20)30374-3

63. China News. The press conference on COVID-19 in Hubei; 2020. Available from: https://m.chinanews.com/wap/detail/zb/2493.shtml. Accessed February 19, 2020. [in Chinese].

64. Guan WJ, Ni ZY, Hu Y, et al. Clinical characteristics of 2019 novel coronavirus infection in China. medRxiv. 2020. doi:10.1101/ 2020.02.06.20020974

65. Chen SM, Yang JT, Yang WZ, et al. COVID-19 control in China during mass population movements at New Year. Lancet. 2020;395 (10226):764-766. doi:10.1016/S0140-6736(20)30421-9

66. Richard H. Offline: 2019-nCoV outbreak-early lessons. Lancet. 2020;395(10221):322. doi:10.1016/S0140-6736(20)30212-9
Risk Management and Healthcare Policy

\section{Publish your work in this journal}

Risk Management and Healthcare Policy is an international, peerreviewed, open access journal focusing on all aspects of public health, policy, and preventative measures to promote good health and improve morbidity and mortality in the population. The journal welcomes submitted papers covering original research, basic science, clinical \& epidemiological studies, reviews and evaluations,

\section{Dovepress}

guidelines, expert opinion and commentary, case reports and extended reports. The manuscript management system is completely online and includes a very quick and fair peer-review system, which is all easy to use. Visit http://www.dovepress.com/testimonials.php to read real quotes from published authors. 